\title{
RELATIONSHIP BETWEEN BORE-HOLE CLOSURE AND CRYSTAL FABRICS IN ANTARCTIC ICE CORE FROM CAPE FOLGER
}

\author{
By Richard J. Thwaites, Christopher J. L. Wilson, \\ (School of Earth Sciences, University of Melbourne, Parkville, Victoria 3052, Australia) \\ and Anthony P. MaCray \\ (Antarctic Division, Department of Science, Kingston, Tasmania 7150, Australia)
}

Abstract. Two holes were drilled to depths greater than $300 \mathrm{~m}$ in the Antarctic ice sheet, near Cape Folger on the Law Dome. The holes underwent considerable closure below $250 \mathrm{~m}$ with localized strain-rates as high as 1 to $1.5 \times 10^{-6} \mathrm{~s}^{-1}$. The closure observed in the holes was non-uniform and occurred in zones 0.5 to $3 \mathrm{~m}$ wide. These zones parallel the flow plane in the ice mass and are associated with a distinct domainal structure. High-closure zones are characterized by interlocking and irregular-shaped ice grains with many sub-horizontal $c$-axes and only occasional $c$-axis clusters at a high angle to the flow plane. Low-closure zones contain tabular grains with the long dimension parallel to the flow plane, abundant deformation features and a predominance of $c$-axes oriented at a high angle to the flow plane. The relationship between closure rate and $c$-axis fabric is attributed to marked plastic flow by intracrystalline slip on the basal plane to produce higher closure in areas where there is a greater variation in $c$-axis orientation. This deformation is attributable to overburden pressure and hence is related to depth, and is independent of shear within the main body of the ice mass.

RÉsumÉ. Relation entre vilesse de fermeture d'un trou de forage et l'orientation des cristaux dans la glace à Cape Folger (Antarctique). On a exécuté deux forages à des profondeurs supérieures à $300 \mathrm{~m}$ dans la calotte antarctique près de Cape Folger sur le Law Dome. Les trous se sont refermés très rapidement en-dessous de $250 \mathrm{~m}$ avec des vitesses pouvant atteindre localement $1,5 \times 10^{-6} \mathrm{~s}^{-1}$. La fermeture observée dans les trous n'est pas uniforme et s'observe dans des couches de 0,5 à $3 \mathrm{~m}$ d'épaisseur. Ces zones sont parallèles au plan d'écoulement dans la masse glaciaire et sont associées à un type particulier de structure. Les zones à fermeture rapide sont caractérisées par des grains de glace entremèlés et de formes irrégulières avec beaucoup d'axes- $c$ subhorizontaux et seulement de rares grappes de cristaux à axes- $c$ formant un angle important avec le plan de l'écoulement. Les zones à fermeture lente contiennent des grains tabulaires avec la grande dimension parallèle au plan de l'écoulement, beaucoup de figures de déformation et

\section{IN TRODUC TION}

A number of authors (Gow, 1986; Paterson, 1977) have recorded varying degrees of closure within drill holes in Antarctic ice. Such closure occurs after a hole has been drilled and before it is filled with fluid of the same density as the ice, in order to counteract closure. The closure of the drill holes is attributed to the plastic flow of the ice as a result of the stress drop following the removal of the core. The extent of closure is dependent in part on the magnitude of the vertically imposed overburden load and on the previous deformation and thermal history of the ice. In the case of the two drill holes described here, BHC 1 and BHC 2 from the Law Dome near Cape Folger, Antarctica (Fig. 1), closure-rate measurements were obtained over $37 \mathrm{~h}$ and $49 \mathrm{~h}$ respectively before the holes were fluid filled. It is the purpose of this paper to describe the features associated with areas of high closure in the two holes and investigate the influence of the ice grain structure and fabric.

The data described in this paper were obtained from small sections of ice core recovered after the two holes were drilled during the $1981 / 82$ austral summer as part of an ANARE (Australian National Ant- une prédominance d'axes-c formant un angle élevé avec le plan d'écoulement. La relation entre la vitesse de fermeture et l'orientation des axes- $c$ est attribuée à l'écoulement plastique sensible par glissements intercristallins sur le plan de base qui produit une fermeture plus rapide dans les régions où il y a une plus grande variation dans l'orientation des axes- $c$. Cette déformation peut être attribuée aux pressions d'enfouissement et donc mise en relation avec la profondeur, elle est indépendante du cisaillement à l'intérieur de la masse de glace.

Zusammenfassung. Beziehung zwischen dem Bohrlochschliessen und dem Kristallgefüge in antarktischen Bohrkernen von Cape Folger, Antarktika. Nahe bei Cape Folger auf dem Law Dome wurden zwei Bohrungen in Tiefen von mehr als $300 \mathrm{~m}$ in den antarktischen Eisschild abgeteuft. Die Bohrlöcher schlossen sich unterhalb von $250 \mathrm{~m}$ beträchtlich mit festgestellten Spannungsraten bis zu $1-1,5 \times 10^{-6} \mathrm{~s}^{-1}$. Die in den Bohrlöchern beobachtete Schliessung erfolgte unregelmässig und trat in Zonen von $0,5-3 \mathrm{~m}$ Länge auf. Diese Zonen verlaufen parallel zu den Fliessflächen in der Eismasse und sind mit einer bestimmten ortstypischen Struktur verknüpft. Zonen schneller Schliessung sind durch ineinandergreifende und unregelmässig geformte Eiskörner mit vielen subhorizontalen $c$-Achsen und nur gelegentlich auftretenden $c$-Achsen-Häufungen unter grossem Winkel gegen die Fliessfläche gekennzeichnet. Zonen geringer Schliessung enthalten tafelförmige Körner mit Längsachsen parallel zur Fliessfläche, unzähligen Deformationserscheinungen und einer vorherrschenden $c$-AchsenOrientierung mit grossem Winkel gegen die Fliessfläche. Die Beziehung zwischen der Schliessungsrate und dem $c$-Achsen-Gefüge wird darauf zurückgeführt, dass deutlich plastisches Fliessen infolge intrakristallinen Gleitens an der Basisebene eine schnellere Schliessung dort verursacht, wo eine grössere Streuung in der $c$-Achsen-Orientierung besteht. Diese Deformation lässt sich dem Überlagerungsdruck zuordnen und hängt deshalb von der Tiefe $a b$; sie ist unabhängig von der Scherspannung im Gesamtkörper der Eismasse.

arctic Research Expedition) glaciological investigation into the ice dynamics of the Law Dome ice cap (McCray, 1982). The hole, BHC 1, was drilled on a bedrock rise (Fig. 2) where the ice was $301 \mathrm{~m}$ deep. BHC 2 was drilled in a bedrock hollow $350 \mathrm{~m}$ downstream where the ice thickness was $345 \mathrm{~m}$. In both holes high bore-hole closure was noted at depths greater than $250 \mathrm{~m}$ (Figs 3 and 4 ) and appear to be local and independent of the large shear strains and movement patterns observed in the bulk of the ice cap (Russell-Head and Budd, 1979; unpublished data of A.P. McCray). The closure rates were determined by measuring the hole diameter after the core had been removed and the hole reamed.

The temperature profiles measured in both BHC 1 and $B H C 2$ after fluid filling are almost 1 inear. In BHC 1 , the temperature ranged form $-1.9^{\circ} \mathrm{C}$ at $280 \mathrm{~m}$ depth to $-1.0^{\circ} \mathrm{C}$ at $300 \mathrm{~m}$, and in $\mathrm{BHC} 2$ from $-2.8^{\circ} \mathrm{C}$ at $280 \mathrm{~m}$ to $-1.2^{\circ} \mathrm{C}$ at $325 \mathrm{~m}$ depth. Samples used for crystal-fabric analysis were selected on the basis of closure rate. As the ice grain-size was large it was sometimes necessary to cut two or even three sections to get an acceptable number of $c$-axis measurements to characterize the fabrics. The $c$-axes were measured using the method described by Langway (1958) and have been plotted on the lower hemisphere of an equal-area projection. 

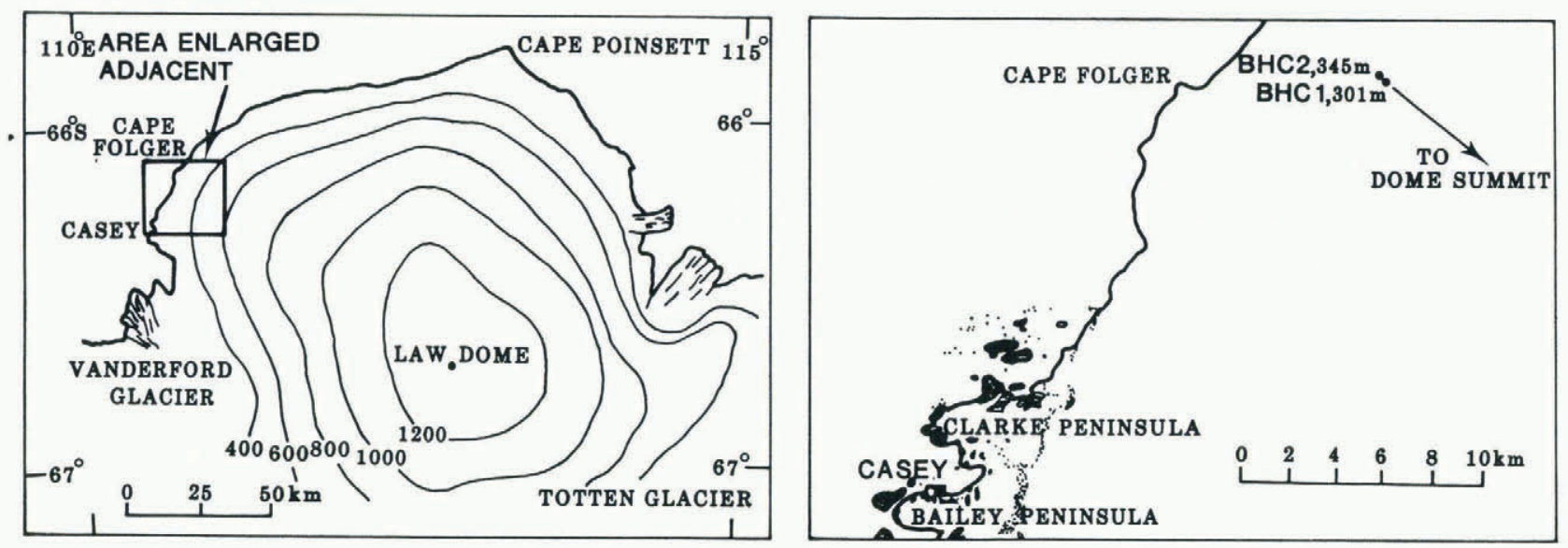

Fig. 1. Locality diagram of BHC 1 and BHC 2 on the Law Dome, Antarctica. $\stackrel{\text { surface flow }}{\rightarrow \text { direction }}$

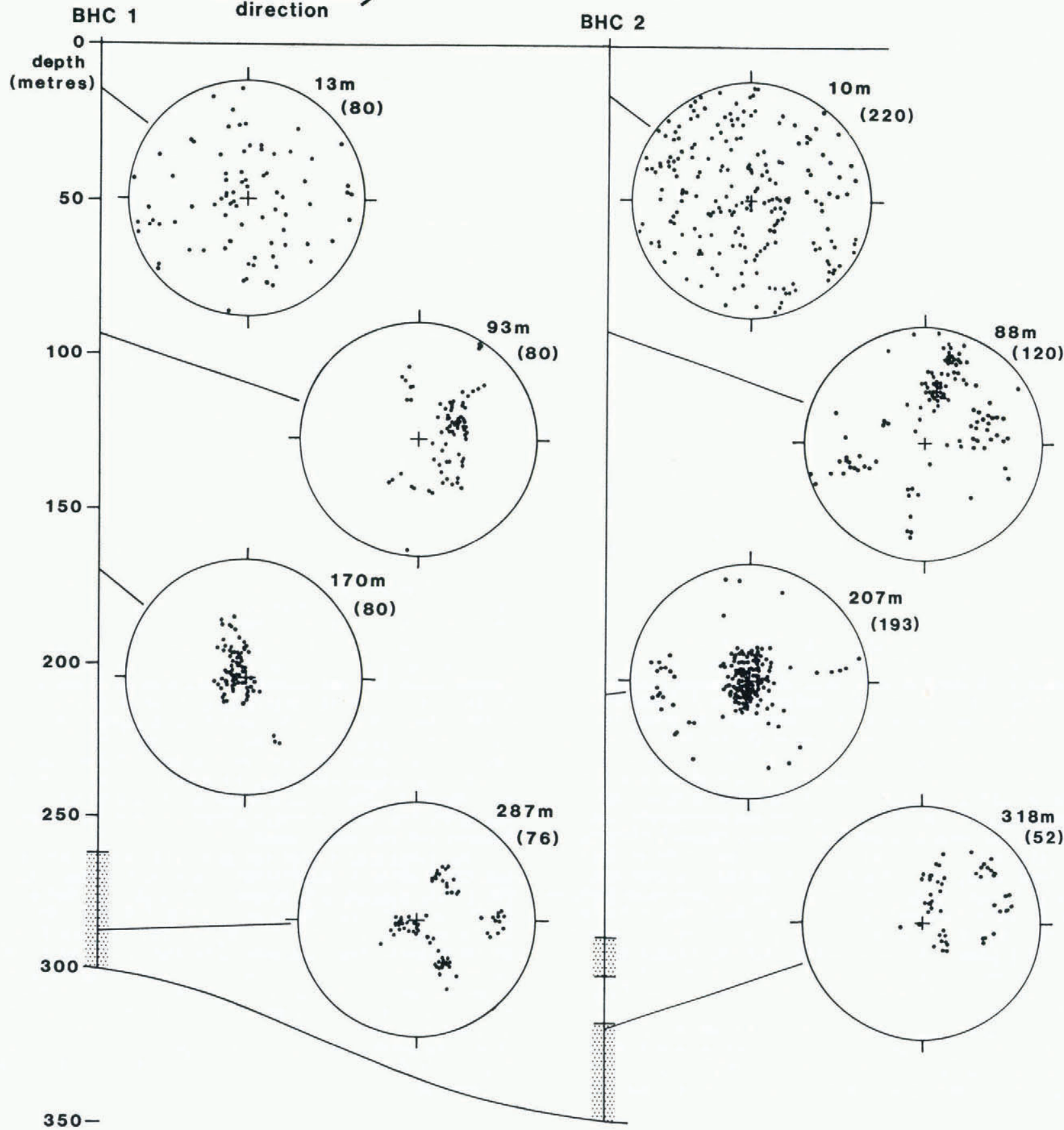

Fig. 2. Schematic profile ill ustrating the relationship of BHC 1 and BHC 2 to bedrock topography and showing areas of high bore-hole closuce (stippled) and the general variation of c-axis preferred orientation through the ice sheet. (80) - number of c-axes measured. 


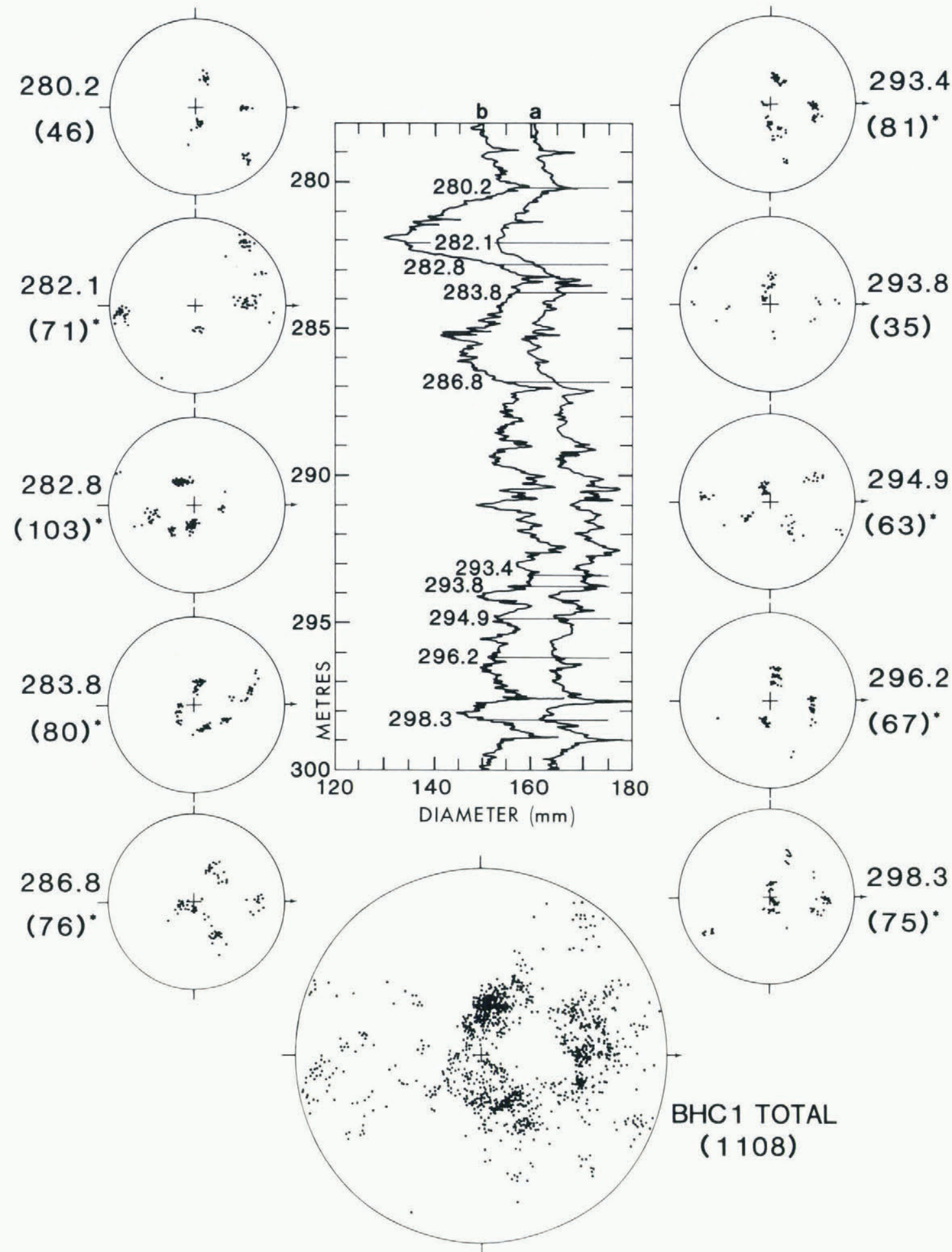

Fig. 3. Diameter of BHC 1 from 278 to $300 \mathrm{~m}$ illustrating the change in hole diameter from Calliper Rum a $(t=0 \mathrm{~h})$ to Calliper Rin $b(t=37.25 \mathrm{~h})$. Selected representative lower hemisphere fabric diagrams with corresponding depths are shown, with a total plot of all the c-axes measured between $278 \mathrm{~m}$ and $300 \mathrm{~m}(80)-$ number of c-axes measured. * - asterisk indicates more than one section from this depth was used to obtain c-axis data. Bubble elongation is east-west and direction of flow is indicated by arrow. 


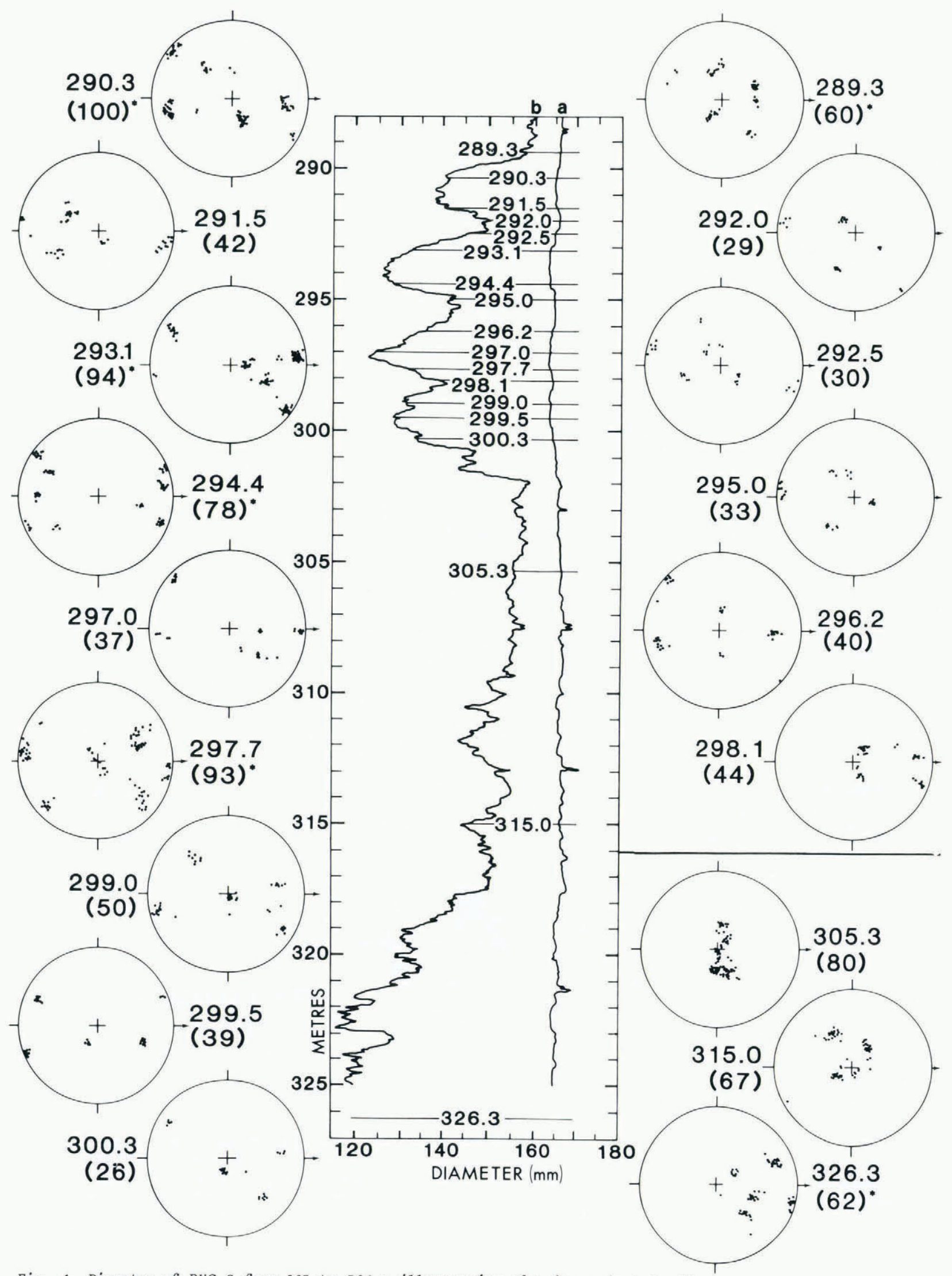

Fig. 4. Diameter of BHC 2 from 287 to $326 \mathrm{~m}$ illustrating the change in hole diameter from Calliper Run a $(t=0 h)$ to Calliper Rim $b(t=49.25 \mathrm{~h})$. Fabric diagrams corresponding to areas of higher or intermediate closure within the interval 289 to $302 \mathrm{~m}$ are arranged on the left. Fabric diagrams on the right (285.3 to 298.1) correspond to areas of lower closwe. The fabric diagrams at $305.3,315$ and $326.3 \mathrm{~m}$ occur outside the zone of bore-hole closure. For explanation of fabric diagrams see Figure 2. 


\section{CLOSURE CHARACTERISTICS}

In BHC 1, areas of bore-hole closure could be identified from the time of the initial calliper run (Fig. 3), that is some $27 \mathrm{~h}$ after the final reaming of the hole. Two areas of high closure between 280 and $288 \mathrm{~m}$ occupy 2-3 m lengths of the hole and are bounded by transition zones of 1-2 m intervals. Below this is a region of variable closure rate in which there are small 0.5 to $1 \mathrm{~m}$ intervals of moderate closure, extending to the bottom of the hole.

Typical closure characteristics recognized in $\mathrm{BHC}$ 2 (Fig. 4) suggest that there is a marked region of increased closure at a depth of 289-302 m. Within this zone the closure rate is variable but occurring in a regular pattern as four zones of very high closure (1-2 m wide) at $3 \mathrm{~m}$ intervals with lower closure between. Below $302 \mathrm{~m}$ a zone of low closure occurs, becoming more variable towards $318 \mathrm{~m}$, where a progressive increase begins, extending to a region of high closure below $322 \mathrm{~m}$. No closure measurements were made in the bottom $20 \mathrm{~m}$ of the hole, that is below $325 \mathrm{~m}$.

\section{FABRIC TRANSITIONS}

The general pattern of $c$-axis variation down the cores is depicted in Figure 2, and is similar to that described by Russell-Head and Budd (1979) from holes drilled up-stream from BHC 1 and BHC 2. In the upper levels of the ice cap a near-random fabric gradually concentrates toward a small circle girdle with increasing depth. An asymmetric fabric forming a partial girdle then develops at about $90 \mathrm{~m}$ which concentrates to a vertical, single-point maximum extending to $230 \mathrm{~m}$ in BHC 1 and $250 \mathrm{~m}$ in BHC 2. Below these depths the ice develops a multi-maxima fabric which persists through the areas of high and variable closure illustrated in Figures 3 and 4 . At the start of the high-closure regions in both BHC 1 and BHC 2 the ice has a large crystal size (Fig. 5). Such crystal sizes and fabrics persist to the base of the ice sheet in $\mathrm{BHC} 1$. In $\mathrm{BHC} 2$ a zone of multi-maxima and variable fabrics (Fig. 4) is recognized to $302 \mathrm{~m}$, below which the grain-size decreased dramatically and the grain $c$-axes concentrate to a near-vertical orientation (as at $305.3 \mathrm{~m}$ ). The ice in the zone of the irregular closure at $315.0 \mathrm{~m}$ is intermediate between the small grain-size ice with strong vertical $c$-axis concentration $(305.3 \mathrm{~m})$ and the large grainsize multiple-maxima ice from the region of very high closure below $(326.3 \mathrm{~m})$. At $315.0 \mathrm{~m}$, many grains are larger than at $305.3 \mathrm{~m}$, however, they do not have stable grain boundaries as at $326.3 \mathrm{~m}$, they have serrated and irregular boundaries, and show strong deformation features. The fabric also appears to be intermediate as there are two strong concentrations of $c$-axes close to the vertical, but a concentration of grains with $c$-axes at a high angle to the vertical is also present.

Near the base of BHC 1 , where the closure is moderate to high, variable multiple-maxima type fabrics occur (Fig. 3). The maximum concentrations tend to form a diamond type pattern $(280.2,293.8,286.8$, $296.2 \mathrm{~m})$, though in some cases a partial diamond pattern may exist with grains of other orientations $(294.9,298.3 \mathrm{~m})$. The only markedly different fabric in the measured sections comes from the peak of a high-closure zone at $282.1 \mathrm{~m}$, where a much greater concentration of sub-horizontal c-axes exists. In the zone of variable closure (293.4-298.3 m), the fabrics (on the right-hand side in Fig. 3), are variable and in some cases show more scattered concentrations of the grain $c$-axes $(193.8,294.9 \mathrm{~m})$.

A plot of all $c$-axes measured in BHC 1 over the interval $279 \mathrm{~m}$ to $300 \mathrm{~m}$, using bubble elongation direction as a reference, clearly illustrates a smal1circle girdle concentration centred on the bubble elongation direction (Fig. 3). The axis of the small circle is inclined $60^{\circ}$ to the direction of flow, with $c$-axes outside the girdle tending to lie along the bubble elongation in an "up-stream" direction. There is an obvious lack of grains with $c$-axes oriented across the ice-sheet flow direction.

In BHC 2 there is a clear demarcation between fabrics that correspond to zones of high closure and those corresponding to zones of low closure (Fig. 4). The high-closure zones invariably show a high concentration of sub-horizontal or gently plunging $c$-axes, together with occasional c-axis clusters oriented at a high angle to the flow plane. Multi-maxima diamond fabrics with the c-axes falling within the smallcircle girdle, as seen in BHC 1 (Fig. 3) are not found in these regions of high closure. In contrast, the low-closure zones show discrete steep plunging $c$-axis concentrations with minor sub-horizontal $c$-axis concentrations (e.g. 289.3, 292.0, 292.5, 295.0, 296.2, $298.1 \mathrm{~m})$.

The difference in grain orientations between high and low closure zones can easily be seen in Figure 6 . Figure $6 a$ shows the total plot of all grains measured in high-closure zones. Most of the grains are oriented sub-horizontally, and appear to lie on a small-circle girdle centred on the flow direction. In Figure $6 \mathrm{~b}$, from the zones of low closure, although a clear girdle pattern has not developed, there is a strong concentration of the grain $c$-axes toward the vertical.

\section{MICROSTRUCTURAL CHARACTERISTICS}

Horizontal sections in flow plane

Local variations in the closure rate are commonly found related to variations in grain-size and structure. In the multiple-maxima ice at the base of BHC 1, zones of higher and lower closure are typically characterized by different grain structures (Fig. 6). In a high-closure zone, the grains are strongly interlocking with irregular and serrated grain boundaries (Fig. $5 a, e)$. In comparison the grains found in a a lowclosure zone have a more regular shape, a much larger maximum grain-size, and have gently curved boundaries (Fig. 5b,f). Deformation features such as undulatory extinction and deformation bands, and strong bubble elongation are present throughout this region of the core. In BHC 2, the microstructural changes (Fig. $5 \mathrm{C}$, d) are similar to those of BHC 1 .

\section{Vertical sections across the flow plane parallel to} bubble elongations

The vertical sections display a grain-size contrast between zones of high (Fig. $5 \mathrm{~g}$ ) and $1 \mathrm{ow}$ closure (Fig. 5h). In the low-closure zones, grains tend to be tabular with the long dimension oriented parallel to the flow plane (Fig. $5 \mathrm{~h}$ ), whereas in the highclosure zones, grains show little elongation, are irregular and interlocking with deformation bands.

As the c-axes of many grains are contained within the plane of the vertical section, these sections have the advantage that they intersect the basal plane at a high angle. As a consequence, crystallographically controlled deformation features such as deformation lamellae and deformation bands (Fig. 7a, b) become more apparent than in the corresponding horizontal section. These features are particularly obvious in the major area of closure in BHC 2 (289$302 \mathrm{~m}$ ) and in the large grains associated with lower closure zones. Another feature developed in these grains is a blocky extinction pattern (Fig. 7c), which is a result of a deformation band being terminated by a microfracture (Fig. 7c) sub-parallel to the basal deformation lamellae. This produces local lattice bending across a smali portion of the grain. The expression of this deformation feature in the horizontal section is rippled extinction (Fig. 5d) where small distinct areas of the grain have different extinction. 

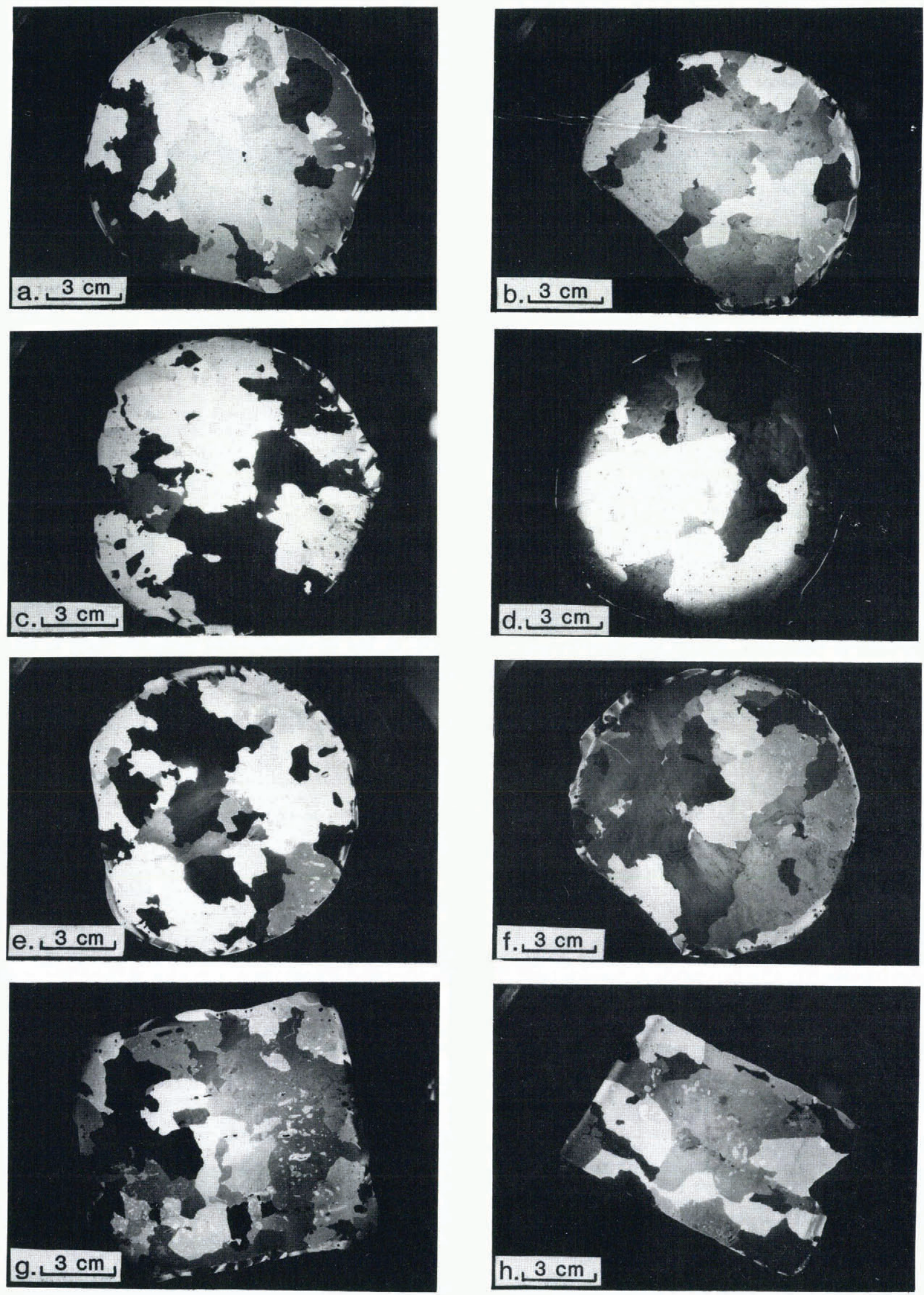

Fig. 5. Ice-grain structures, with bar scale shown. The sections from high and intermediate closure zones are on the left. (a) horizontal section in BHC 1 at $282.1 \mathrm{~m}$, (b) horizontal section in BHC 1 at $278.9 \mathrm{~m}$, (c) horizontal section in BHC 2 at $297.7 \mathrm{~m}$, (d) horizontal section in BHC 2 at $289.0 \mathrm{~m}$, (e) horizontal section in BHC 1 at $298.3 \mathrm{~m}$ with corresponding vertical section $(g)$, ( $f$ ) horizontal section in BHC 1 at $290.0 \mathrm{~m}$ with corresponding vertical section $(h)$. 

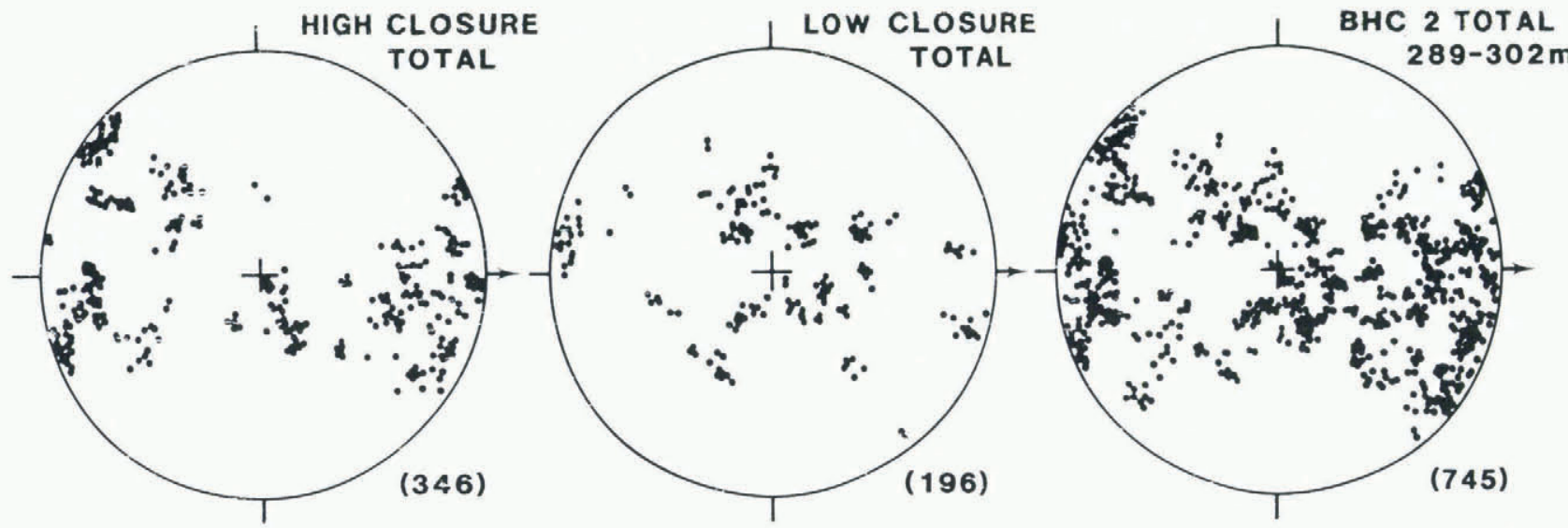

Fig. 6. Summary of c-axis patterns within the high closwe interval, 289-302 $\mathrm{m}$ in BHC 2 . (a) zones of high closwe, (b) zones of low closwe, (c) total c-axes measured between $289-302 \mathrm{~m}$, which includes data collected between the high and low closure zones. The total plots are aligned with reference to the bubble elongation and the known elongation of a scribe mark on the ice core.
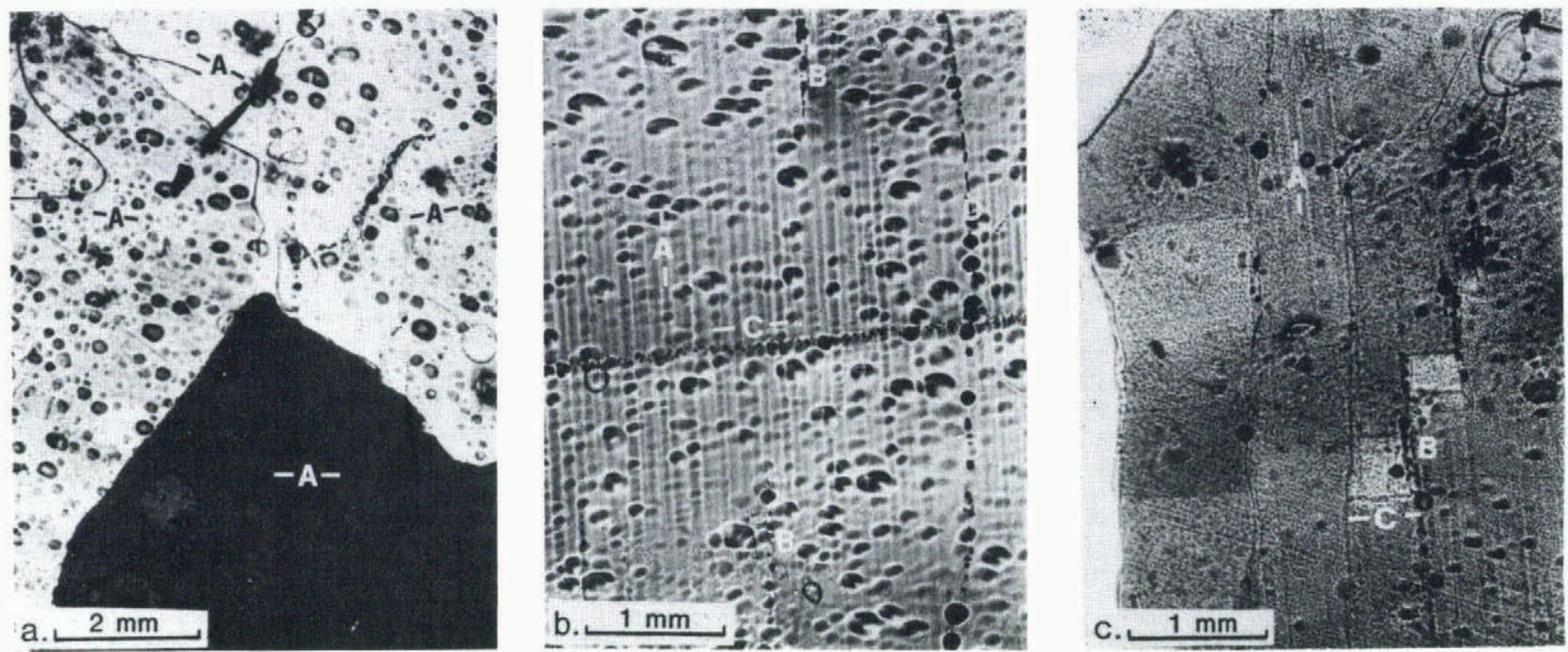

Eig. 7. Micrographs of deformation features in vertical thin sections of ice from $282.1 \mathrm{~m}$ in BHC 1. (a) Deformation lameliae (A) in fous separate grains. (b) Deformation lamellae (A) and parallel microfractures (B) perpendicular to bubble trace (C) along a deformation band boundary paraliel to the trace of the c-axis. Sub-horizontal bubble traces (D) are rehealed expansion cracks. (c) The blocky extinction pattern produced by the deformation lamellae (A) and parallel microfaults (B) with grain misorientations across deformation band boundaries.

\section{DISCUSSION}

This study supports the idea (Gow, 1963, 1970; Paterson, 1977) that bore-hole closure in ice masses is a result of plastic flow in a pure shear environment and is attributable to overburden pressure. It also confirms the observation of Gow (1963) that closure rate is dependent on depth. In BHC 1 and BHC 2 the pattern of closure rate is condiderably less regular than that described by Gow (1963) and was only observed bel ow $250 \mathrm{~m}$, whereas Gow's closure began at about $150 \mathrm{~m}$ and increased to the base of the hole at $309 \mathrm{~m}$. The measured strain-rates were two orders of magnitude higher in zones of high closure near the base of the Law Dome, being $1.12 \times 10^{-6} \mathrm{~s}^{-1}$ at $282 \mathrm{~m}$ in BHC 1 and $1.54 \times 10^{-6} \mathrm{~s}^{-1}$ at $325 \mathrm{~m}$ in BHC 2 measured after less than two days, compared to Gow's results at $305 \mathrm{~m}$ ranging from $6.3 \times 10^{-9} \mathrm{~s}^{-1}$ after one year, to $2.8 \times 10^{-8} \mathrm{~s}^{-1}$ after four years. Another difference with previous published results of closure in Antarctic ice is that the temperatures in the Byrd hole were about $-28^{\circ} \mathrm{C}$, and the $\mathrm{closure}$ measurements were only taken to $309 \mathrm{~m}$ in an ice sheet over $2 \mathrm{~km}$ thick. In this hole the fabrics varied only slightly from a random scatter, concentrating towards a small-circle girdle at $309 \mathrm{~m}$. In comparison the temperatures of the thin ice sheet at the Law Dome varied from approximately $-10^{\circ} \mathrm{C}$ at the surface to $-1.0^{\circ} \mathrm{C}$ (BHC 1) and $-0.5^{\circ} \mathrm{C}$ (BHC 2) at the bottom of the holes, and a complete progression of $c$-axis fabrics and structures was found from a random fabric, through a smallcircle girdle and a fine-grained vertical singlepoint maximum, to coarse-grained multiple-maxima fabrics near the base. Based on experimental data (e.g. Mellor, 1980) the higher temperatures and the different fabrics probably contribute to the much higher strain-rates found in the Cape Folger ice.

Under the warm, shallow conditions found on the Law Dome, areas of bore-hole closure are expressions of the prevailing fabric (Figs 3 and 4 ). For example, in BHC 2 (Fig. 4), section 305.3 lies within a zone of low and fairly stable bore-hole closure rate. The 
ice has a fine grain-size and shows a concentration of $c$-axes towards the vertical, that is, the basal planes are aligned sub-horizontally. Ice with such a fabric would be suitably oriented for a simple shear deformation, but not for pure shear deformation. Whereas much coarser-grained ice with a more scattered multiple-maxima fabric, as found at $326.3 \mathrm{~m}$, occurs in zones of very high closure rate. The basal planes in the latter ice would have more varied orientations, so, assuming basal-plane glide is the dominant mechanism of deformation, this ice would be more resistant to flow by simple shear, but more susceptible to vertical compression and lateral extension in a pure shear environment as a result of overburden pressure. Closure rate also varies within the zone of high closure in BHC 2 between 289 and $302 \mathrm{~m}$. This variation is cyclic (Fig. 4) having a wavelength of about $3 \mathrm{~m}$. The regions of high and low closure correspond to particular fabric types, indicating a domainal structure within the ice. The ice in the zones of lower closure show multiple-maxima fabrics distributed around the vertical, whereas there is a greater concentration of c-axes towards the horizontal in zones of higher closure.

The concept of regions of domainal fabric in naturally occurring materials has been discussed by numerous authors. Turner and Weiss (1963, p. 20-21) and Hobbs (1966, p. 699) have suggested that heterogeneities of stress may develop on a small scale, during the homogeneous deformation of a solid body, resulting in variation in fabric and structure. Such domainal fabric variation on a microscale has been described in deformed metamorphic rocks by Hobbs (1966) and also by Sander (1970, p. 403-13). Although on a vastly different scale the domainal fabrics and structures in the high-closure zone in BHC 2 are similar to those seen in quartzites. For example, the Rensenspitze quartzite (Sander, 1970, plate 11b, p. 637) shows a strongly domainal fabric pattern. Layers with c-axes concentrated as maxima on a small-circle girdle perpendicular to the foliation. An analogous variation in fabrics is found in the ice between 289 and $302 \mathrm{~m}$ in BHC 2 where the pattern of sub-horizontally oriented grains in the higher-closure zones is equivalent to the $c$-axes oriented perpendicular to the foliation in Sander's quartzite, but is more scattered in the ice. Again there appears to be a similar relationship between the grain-size and the periodicity of the fabric change. In forty traverses taken across plate $11 b$ (Sander, 1970, p. 637), an average of 23.6 grain boundaries were crossed between the centres of layers of similar fabric. The periodicity of a similar change in the glacier ice was a little under $3 \mathrm{~m}$, so to cross an equivalent number of grain boundaries would require grains with an average size of $12.7 \mathrm{~cm}$. The average grain-size in this ice, calculated by the mean linear intercept method (Pickering, 1976) is lower, in the order of 2-3 cm, however the maximum grain-size in many sections is larger than $12.6 \mathrm{~cm}$. The difference between the measured ice grain-size and that expected may be attributable to minor irregularities counted in the boundaries of ice grains which are not visible in the quartz AVA diagram, and also to the highly interlocking nature of the ice which would tend to decrease the average grain-size measured.

It is well recognized (Bouchez and others, 1983; Wilson, 1979) that there are analogies between the physical behaviour and the development of microfabrics in ice and quartz. Another study that has a bearing on the origin of the domainal structure in $\mathrm{BHC} 2$ is the study of Celma (1982) who finds a crossed twogirdle total fabric (in a plane perpendicular to the foliation) similar to that obtained by Ramsauer, (in Sander, 1970). On the basis of the fabrics and the microstructure, Celma (1982) divides the mylonite into three domainal types, with grain $c$-axes oriented in the two girdles, and also at the centre of the diagram. The presence of all three domains is dependent on the amount of shear deformation undergone by the sample (Celma, 1982, p. 446) and that with increasing shear strains, one of the girdles disappears. Hudleston (1977) shows a similar change across a shear zone in ice from the Barnes Ice Cap. In the centre of the shear zone however, where the strain is much greater, the $c$-axes concentrated to a vertical single-point maximum. So the extent of development of the domainal structures may depend on the shear strain. Under very high shear strain, the material may lose its inhomogeneities of structure and fabric, adopting a single-point $c$-axis fabric. In BHC 2 the region of high closure (289-302 m) occurs between two zones of very low closure, which contain fine-grained ice with a vertical singlemaximum fabric undergoing simple shear (unpublished data of A.P. McCray). The higher closure zone containing the larger crystal size is subjected to less simple-shear deformation which may allow the local development of stress heterogeneities and the subsequent development of domainal structures and fabrics.

Another factor which may effect the development of the c-axis fabrics is the bedrock topography. BHC 2 is drilled in a bedrock hollow, $50 \mathrm{~m}$ deeper than BHC 1 and $250 \mathrm{~m}$ down-stream. Oxygen-isotope studies (unpublished data of A.P. McCray) suggest that there has been a component of vertical stretching of the ice column in BHC 2. This also accounts for the difference in depth where there is a change of ice types from fine-grained single-maximum to large-grained multiple-maxima, occurring at $230 \mathrm{~m}$ in BHC 1 and at $250 \mathrm{~m}$ in BHC 2. Perhaps this vertical stretching of the ice could change the stresses and so the fabrics within the glacier.

\section{CONCLUSIONS}

Measurements of the bore-hole diameter with depth through two bore holes on the Law Dome, Antarctica, and subsequent measurements of the c-axis fabrics at selected depths indicate that the closure rate is highly variable and is closely related to the $c$-axis fabric of the ice. The main features relating fabric to closure rate have become apparent:

1. A single-point vertical concentration of c-axes in fine-grained ice produces very low and stable closure rates.

2. Large-grain multiple-maxima ice undergoes much higher and more variable closure. Within this ice are two types of fabric/closure relationships: (a) grains concentrating in a diamond pattern near the vertical result in a lower closure.

(b) grains with c-axes concentrating towards the sub-horizontal at a low angle to the flow direction result in higher closure. Transition in fabric and closure are found between these different types of ice.

3. At the base of the ice sheet in BHC 1, the multiple-maxima fabrics in the zone of high'closure tend to lie within a small-circle girdle. The grains within the girdle show substantial deformation features, including deformation bands, deformation lamellae, and irregular extinction, whereas the grains oriented outside the girdle show few or no deformation features. This difference may result from the grains within the girdle being more deformed as they are much older and more stable under the long-term stress conditions, whereas the relatively undeformed grains outside the girdle are younger and exist only briefly as a result of local inhomogeneities of the stress. Another explanation may be that the amount of deformation undergone by any grain is a function of its orientation within the existing stress field. 
4. In the zone of high closure (289-302 $\mathrm{m}$ ) in BHC 2, more varied fabrics and grain structures occur in a cyclic or domainal distribution pattern, so a small-circle girdle does not develop in the total fabric plot.

5. The domainal c-axis fabric patterns are formed by the development of inhomogeneities of the shear stress in a similar manner to that described on a small scale in naturally occuring shear zones in rocks.

\section{ACKNOWLEDGEMENTS}

This research was extensively supported by the Australian Antarctic Divion, members of the 1981-82 A.N.A.R.E. and in part by an A.R.G.S. grant to C.J.L.W. I.F. Allison and T.H. Jacka are thanked for their comments on an earlier draft of this paper and W.F. Budd and S.H. White are thanked for stimulating discussions.

\section{REFERENCES}

Bouchez, J.L., and others. 1983. Fabric asymmetry and shear sense in movement zones, by J.L. Bouchez, G.S. Lister, and A. Nicholas. Geologische Rundschau, Bd. 72, Ht. 2, p. 401-19.

Celma, A.G. 1982. Domainal and fabric heterogeneities in the Cape de Creus quartz mylonites. Jownal of Structural Geology, Vol. 4, No. 4, p. 443-55.

Gow, A.J. 1963. Results of measurements in the 309 meter bore hole at Byrd Station, Antarctica. Joumal of Glaciology, Vol. 4, No. 36, p. 771-84.

Gow, A.J. 1970. Preliminary results of studies of ice cores from the $2164 \mathrm{~m}$ deep drill hole, Byrd Station, Antarctica. [Union Géodésique et Géophysique Internationale. Association Internationale d'Hydrologie Scientifique.] [International comcil of Scientific Unions. Scientific Committee on Antarctic Research. International Association of Scientific Hydrology. Commission of Snow and Ice.] International Symposium on Antarctic Glaciological Exploration (ISAGE),
Hanover, New Hampshire, U.S.A., 3-7 September 1968, p. 78-90. [(Publication No. $86^{\prime}$ [de 1'Association Internationale d'Hydrologie Scientifique].)]

Hobbs, B.E. 1966. Microfabric of tectonites from the Wyangala Dam area, New South Wales, Australia. Geological Society of America. Bulletin, Vol. 77, No. 7 , p. 685-706

Hudleston, P.J. 1977. Progressive deformation and development of fabric across zones of shear in glacial ice. (In Saxena, S., and Bhattacharji, S., ed. Energetics of geological processes. New York, Springer-Verlag, p. 121-50.)

Langway, C.C., jr. 1958. Ice fabrics and the universal stage. U.S. Snow, Ice and Permafrost Research Establishment. Technical Report 62.

McCray, T. [i.e. A.P.] 1982. Cape Folger ice drilling. ANARE News, 1982, No. 16, p. [12].

Mellor, M. 1980. Mechanical properties of polycrystalline ice. (In Tryde, P., ed. International Union of Theoretical and Applied Mechanics. Physics and mechanics of ice. Symposium, Copenhagen, August 6-10, 1979. Technical University of Denmark. Berlin, etc., Springer-Verlag, p. 217-45.)

Paterson, W.S.B. 1977. Secondary and tertiary creep of glacier ice as measured by borehole closure rates. Reviews of Geophysics and Space Physics. Vol. 15, No. 1, p. 47-55.

Pickering, F.B. 1976. The basis of quantitative metallography. Whetstone, Metals and Metallurgy Trust for the Institute of Metallurgical Technicians.

Russel1-Head, D.S., and Budd, W.F. 1979. Ice-sheet flow properties derived from bore-hole shear measurements combined with ice-core studies. Jownal of Glaciology, Vol. 24, No. 90, p. 117-30.

Sander, B. 1970. An introduction to the study of fabrics of geological bodies. Oxford, etc., Pergamon Press.

Turner, F.J., and Weiss, L.E. 1963. Structural analysis of metamorphic tectonites. New York, McGraw$\mathrm{Hi} 11$ Book Co., Inc.

Wilson, C.J.L. 1979. Boundary structures and grain shape in deformed multilayered polycrystalline ice. Tectonophysics, Vol. 57, P. T19-T25. [Letter.] 